\title{
Anti-metastatic effects of isolinderalactone via the inhibition of MMP-2 and up regulation of NM23-H1 expression in human lung cancer A549 cells
}

\author{
CHENG-HUNG CHUANG ${ }^{1}$, LI-YU WANG ${ }^{1}$, YUEN MAN WONG ${ }^{1}$ and EN-SHYH LIN ${ }^{2}$ \\ ${ }^{1}$ Department of Nutrition, Hungkuang University, Taichung 43302; ${ }^{2}$ Department of Beauty Science, \\ National Taichung University of Science and Technology, Taichung 40343, Taiwan, R.O.C.
}

Received May 25, 2017; Accepted December 8, 2017

DOI: $10.3892 / \mathrm{ol} .2018 .7862$

\begin{abstract}
Metastatic lung cancer is a leading cause of mortality and has a mortality rate of $\geq 90 \%$. Isolinderalactone (ILL) is a sesquiterpene lactone compound that has been used in traditional Chinese medicine. Research has demonstrated that ILL has anti-inflammatory and anti-proliferative properties; however, to the best of our knowledge, studies investigating whether ILL can inhibit lung cancer cell metastasis have not been conducted. In the present study, 1-10 $\mu \mathrm{M}$ ILL was applied in the culturing of the A549 lung cancer cell line to investigate the effects of ILL on the invasion and migration of lung cancer cells, including whether the possible mechanisms of ILL are associated with the expression of matrix metalloproteinase (MMP)-2 and NME/NM23 nucleoside diphosphate kinase 1 (NM23-H1) genes. The results of the present study indicated that ILL inhibited the invasion and migration of the A549 cancer cells and exhibited a dose-response association. ILL also significantly inhibited the protein expression and activity of MMP-2 $(\mathrm{P}<0.05)$, exhibiting a trend similar to that of its invasion- and migration-associated properties. Further research revealed that ILL significantly increased the expression of NM23-H1 protein and inhibited the expression of $\beta$-catenin protein $(\mathrm{P}<0.05)$. The results of the present study is, to the best of our knowledge, the first to confirm that ILL can inhibit the invasion and migration of A549 cancer cells, with
\end{abstract}

Correspondence to: Dr En-Shyh Lin, Department of Beauty Science, National Taichung University of Science and Technology, 193, Sec. 1, San-Min Road, Taichung 40343, Taiwan, R.O.C.

E-mail: eslin7620@hotmail.com

Abbreviations: MMP-2, matrix metalloproteinase-2; ILL, isolinderalactone; FOXO3, transcriptional factor fork head box O3; STAT3, signal transducer and activator of transcription 3; CUM, curcumin; DMSO, dimethyl sulfoxide; Nm23-H1, NME/NM23 nucleoside diphosphate kinase 1

Key words: isolinderalactone, matrix metalloproteinase-2, invasion, migration, NME/NM23 nucleoside diphosphate kinase 1, lung cancer cells the possible mechanisms potentially involving the inhibition of MMP-2 and $\beta$-catenin protein expression resulting from the up regulation of NM23-H1 expression.

\section{Introduction}

Cancer is a leading cause of mortality; $\sim 8.2$ million people worldwide succumbed to cancer-associated mortality in 2012, with lung cancer accounting for $\sim 1.59$ million cases of mortality, or $\sim 20 \%$ of the total (1). Lung cancer cell metastasis is a primary cause of mortality and those that experience it have a mortality rate of $\geq 90 \%$ (2). When it metastasizes, lung cancer has a $95 \%$ chance of affecting local lymph nodes and an $80 \%$ chance of affecting other organs $(3,4)$. Thus, in clinical terms, the overall 5-year survival rate from the time of diagnosis to mortality for patients with lung cancer undergoing treatment is only $10-15 \%$ (5). Cancer cell metastasis is a complex multistep process involving invasion and migration (6-8). Matrix metalloproteinases (MMPs) are zinc/calcium-dependent endopeptidases involved in the degradation of the extracellular matrix, two examples of which are MMP-2 and -9 (7,9). MMP-2 is a notable factor in the development of tumor metastasis $(7,10)$. MMP-2 is highly expressed in malignant tumors and serves a key role in cancer invasion and angiogenesis $(7,11)$. The inhibition of MMP-2 is, therefore, an effective strategy for preventing tumor cell metastasis $(11,12)$. The NME/NM23 nucleoside diphosphate kinase 1 (NM23) gene was first identified in the murine melanoma cell line exhibiting high metastatic activity; increasing the expression of this gene may also reduce the metastatic activity of tumor cells (13). When transfected with NM23 genes, a variety of tumor cell types were reported to exhibit the inhibition of metastatic properties, including migration, invasion, and colonization (14-18). The NM23-H1 (NME1) gene was reported to be the one closely associated with the metastasis of cancer cells, including breast, lung and liver cancer (19-21).

Lindera aggregata (Sims) Kosterm is a traditional Chinese herbal medicine often used in Asia. It has been used to treat chest and abdominal pain, indigestion, regurgitation, colds, hernia and frequent urination (22). Studies have demonstrated that L. aggregata extract has antioxidant properties, and can inhibit tumor cell growth and induce apoptosis (23-26). For 
instance, Li et al (23) identified that Lindera strychifolia extract was able to inhibit the growth of lung cancer A549 and SBC-3 cell lines, and induce cell apoptosis. Allografts also produced similar results; L. strychifolia extract was able to inhibit the growth of Lewis lung, A549 and SBC-3 cancer cells, and induce cancer cell apoptosis (23). Isolinderalactone (ILL) is a type of sesquiterpene compound obtained from the root tuber of L. aggregata. Yen et al (27) verified that ILL could induce apoptosis in the human breast cancer MDA-MB-231 cell line, possibly via the inhibition of microRNA hsa-miR-30c expression and increasing the expression of suppressor of cytokine signaling 3 (SOCS3). This in turn inhibits the phosphorylation of signal transducer and activator of transcription 3 (STAT3) and regulates the downstream processing of STAT3 pathways, increasing B-cell lymphoma-2 (Bcl-2) and Bcl-extra large protein expression, and inhibiting $\mathrm{X}$-linked inhibitor of apoptosis expression. A previous study also revealed that sesquiterpene lactone compounds, including ILL, linderalactone and linderane, were able to inhibit the proliferation of the A549 cancer cells, with ILL exhibiting the best inhibitory properties (28). However, it remains unclear whether ILL can inhibit lung cancer cell metastasis and the associated mechanisms require further investigation.

The present study aimed to investigate the effects of ILL on lung cancer A549 cell invasion and migration, as well as the association between potential mechanisms, and the expression of MMP-2 and NM23-H1 genes.

\section{Materials and methods}

Chemicals and reagents. ILL was purchased from Wuhan Chem Faces Biochemical Co., Ltd. (Wuhan, China). RPMI-1640, minimum essential medium-non-essential amino acids, Gluta MAX, trypsin, penicillin, streptomycin, and sodium pyruvate were purchased from Gibco; Thermo Fisher Scientific, Inc. (Waltham, MA, USA). Dimethyl sulfoxide (DMSO) was purchased from Merck KGaA (Darmstadt, Germany). Anti- $\beta$-catenin monoclonal antibody (mAb; cat. no. NBP1-54467), anti-NM23 mAb (cat. no. NBP1-47398) and anti-E-cadherin $\mathrm{mAb}$ (cat. no. NBP2-19051) were purchased from Novus Biologicals, LLC. (Littleton, CO, USA). Anti-MMP-2 mAb (cat. no. 031129) and anti-mouse immunoglobulin G (IgG)-horseradish peroxidase (HRP) antibodies (cat. no. 140769-HRP) were purchased from United States Biological (Salem, MA, USA). Anti-tissue inhibitor metalloproteinase-2 (TIMP-2; cat. no. 5738) $\mathrm{mAb}$ was obtained from Cell Signaling Technology, Inc. (Danvers, MA, USA). Transwell inserts were acquired from Costar; Corning Incorporated (Corning, NY, USA). Matrigel was purchased from BD Biosciences (Franklin Lakes, NJ, USA). Curcumin (CUM) and protease inhibitor cocktail (cat. no. S8820) were obtained from Sigma-Aldrich; Merck KGaA. All chemicals used were of reagent grade or higher.

Cell culture. Human A549 lung cancer cells were obtained from the Bioresource Collection and Research Center, Institute of Biological Resources Conservation and Research (Hsinchu, Taiwan) and were cultured in RPMI-1640 medium containing $10 \%$ (v/v) fetal bovine serum (FBS; Gibco; Thermo Fisher Scientific, Inc.), $0.37 \%$ (w/v) $\mathrm{NaHCO}_{3}$, penicillin (100 U/ml), and streptomycin $(100 \mu \mathrm{g} / \mathrm{ml})$ at $37^{\circ} \mathrm{C}$ in a humidified incubator under $5 \% \mathrm{CO}_{2}$ and $95 \%$ air. An equal number $\left(1 \times 10^{4} / \mathrm{ml}\right)$ of cells were incubated for $24 \mathrm{~h}$ prior to the various treatments. Prior to experimentation, the medium was removed, and the cells were washed twice with PBS. Next, fresh RPMI-1640 medium (with $10 \%$ FBS) containing various concentrations $(1,5,10$, and $20 \mu \mathrm{M})$ of ILL were added andthe samples were incubated for $24 \mathrm{~h}$. In addition, the effects of CUM at a concentration of $10 \mu \mathrm{M}$ were also evaluated and used as a positive control, as CUM has been reported to inhibit the migration and invasion of tumor cells by decreasing protein expression and the activity of MMP-2 in tumor cells $(29,30)$. Stock solutions of ILL and CUM were dissolved in DMSO. Prior to use, the compounds were diluted in $10 \%$ FBS in RPMI-1640 medium to the desired concentrations at the time of addition. The highest concentration of DMSO used did not exceed $0.1 \%(\mathrm{v} / \mathrm{v})$ of the total assay volume, which did not affect cell viability.

Cell growth analysis. Cell growth was assayed as described previously by Yeh et al (31). A549 cells were seeded in 6-well plates at a density of $1 \times 10^{5}$ cells/well and cultured at $37^{\circ} \mathrm{C}$ for 24 and $48 \mathrm{~h}$. Various concentrations of ILL werethen added to the cells to reach final concentrations of $1,5,10$, and $20 \mu \mathrm{M}$ in the presence of FBS. The control group contained $10 \%$ FBS. The cells were then cultured at $37^{\circ} \mathrm{C}, 5 \% \mathrm{CO}_{2}$, and $95 \%$ air for 24 and $48 \mathrm{~h}$, and the trypan blue exclusion protocol was used to determine cell viability, as described previously $(32,33)$. Briefly, an amount of $0.4 \%$ trypan blue dye solution equal to the sample volume was added. After gentle mixing, samples were loaded into a hemocytometer (cat. no. 065003, Marienfeld-Superior, Paul Marienfeld GmbH \& Co. KG, Lauda-Königshofen, Germany) for counting under a microscope at x100 magnification (33).

Cell migration assay. Tumor cell migration was assayed in transwell chambers according to the methods reported by Repesh (34), with certain modifications as previously described by Chuang et al (35). Briefly, transwell chambers with $6.5-\mathrm{mm}$ polycarbonate filters of $8-\mu \mathrm{m}$ pore size were used. Following preincubation with the tested compounds for $\geq 24 \mathrm{~h}$, A549 cells $\left(2.5 \times 10^{5} / \mathrm{ml}\right)$ were suspended in $100 \mu \mathrm{l}$ serum-free RPMI-1640 medium and placed in the upper transwell chamber. RPMI-1640 medium containing 10\% FBS (300 $\mu \mathrm{l}$ ) was placed in the lower transwell chamber to serve as the source of chemoattractant. The transwell was incubated for $12 \mathrm{~h}$ at $37^{\circ} \mathrm{C}$. Subsequently, the cells on the upper surface of the filter were completely wiped away with a cotton swab. The cells on the lower surface of the filter were fixed in methanolat $25^{\circ} \mathrm{C}$ for $10 \mathrm{~min}$, stained with Giemsa at $25^{\circ} \mathrm{C}$ for $1 \mathrm{~h}$, and counted under a microscope (Inverted Microscope; ECLIPSE/TS100; Nikon Corporation, Tokyo, Japan; magnification, x100). For each replicate, the tumor cells in 5 randomly selected fields were determined, and the counts were averaged.

Cell invasion assay. Cell invasion was also assessed using transwell chambers as described in the migration assay; however, each filter was first coated with $100 \mu 1$ of 1:20 diluted Matrigel in cold RPMI-1640 medium (without chemoattractant) to form a thin continuous film on the top of the filter. 
An aliquot (100 $\mu \mathrm{l})$ of serum-free RPMI-1640 containing $5 \times 10^{4}$ cells was added to each of the triplicate wells in RPMI-1640 medium containing 10\% FBS, which served as a chemoattractant in the assay. Following incubation at $37^{\circ} \mathrm{C}$ for $24 \mathrm{~h}$, cells were stained and counted as aforementioned. The number of cells invading the lower side of the filter was measured as representative of invasion activity.

Western blotting. Expression levels of NM23-H1, MMP-2, E-cadherin, $\beta$-catenin and, TIMP-2 proteins were determined by western blotting. Western blot analysis was performed as described previously (35). Briefly, the medium was removed and cells were lysed with protein lysis buffer $(50 \mathrm{mM}$ Tris-HCl buffer $\mathrm{pH}$ 7.4, $1 \mathrm{mM}$ EDTA, 5\% SDS, $1 \mathrm{mM}$ phenylmethylsulfonyl fluoride, $1 \mathrm{X}$ protease inhibitor cocktail). The lysate was sonicated (frequency, $20 \mathrm{kHz}$ ), for $30 \mathrm{sec}$ at $4^{\circ} \mathrm{C}$ followed by centrifugation at $12,000 \mathrm{x}$ g for $30 \mathrm{~min}$ at $4^{\circ} \mathrm{C}$. An amount of protein (40 $\mu \mathrm{g}$ per lane) from the supernatant was resolved by $0.1 \%$ SDS-PAGE and transferred onto a nitrocellulose membrane. Following blocking with Tris-buffered saline buffer (20 mM Tris- $\mathrm{HCl}, 150 \mathrm{mM} \mathrm{NaCl}, \mathrm{pH} 7.4$ ) containing $5 \%$ non-fat milk for $1 \mathrm{~h}$ at $25^{\circ} \mathrm{C}$, the membrane was incubated at $4^{\circ} \mathrm{C}$ for $12 \mathrm{~h}$ with anti-NM23-H1 mAb (1:500 dilution), anti-MMP-2 $\mathrm{mAb}$ (1:500 dilution), anti-E-cadherin $\mathrm{mAb}$ (1:500 dilution), anti- $\beta$-catenin $\mathrm{mAb}$ (1:1,000 dilution) and, anti-TIMP-2 $\mathrm{mAb}$ (1:1,000 dilution) followed by HRP-conjugated anti-mouse IgG (incubated at $25^{\circ} \mathrm{C}$ for $2 \mathrm{~h} ; 1: 5,000$ dilution) and then visualized using an ECL Chemiluminescent Detection kit (EMD Millipore, Billerica, MA, USA). The relative expression levels of NM23-H1, MMP-2, E-cadherin, $\beta$-catenin and TIMP-2 proteins were quantitated using Matrox Inspector version 2.1 software (Matrox Electronic Systems Ltd. Dorval, QC, Canada).

Gelatin zymography assay. MMP-2 activity was assayed using gelatin zymography according to the method reported by Hwang et al (36), with certain modifications, as previously described in a study by Chuang et al (35). The cells $\left(5 \times 10^{4}\right.$ cells $\left./ \mathrm{ml}\right)$ were pretreated with ILL or CUM in RPMI-1640 medium containing 10\% FBS for $24 \mathrm{~h}$. Following two washes with PBS, the cells were incubated in serum-free RPMI-1640 medium for $24 \mathrm{~h}$. Subsequently, the culture medium was harvested and stored at $-20^{\circ} \mathrm{C}$ until use. For the gelatin zymography assay, the culture medium was separated on a $10 \%$ SDS-PAGE gel containing $0.1 \%(w / v)$ gelatin. Following electrophoresis, the gel was washed for $30 \mathrm{~min}$ at room temperature in a solution containing $2.5 \%$ $(\mathrm{v} / \mathrm{v})$ Triton X-100, with two changes, and then transferred to a reaction buffer for enzymatic reaction containing $1 \%$ sodium azide $\left(\mathrm{NaN}_{3}\right), 10 \mathrm{mM}$ calcium chloride $\left(\mathrm{CaCl}_{2}\right)$, and $40 \mathrm{mM}$ Tris-hydrochloride, $\mathrm{pH} 8.0$, at $37^{\circ} \mathrm{C}$ with agitation overnight (for $15 \mathrm{~h}$ ). Finally, the gel was stained at $25^{\circ} \mathrm{C}$ for $30 \mathrm{~min}$ with $0.25 \%(\mathrm{w} / \mathrm{v})$ Coomassie blue in $10 \%$ acetic acid and $50 \%$ methanol and de-stained with $10 \%$ acetic acid and 50\% methanolat $25^{\circ} \mathrm{C}$ for $2 \mathrm{~h}$. The relative MMP-2 activities were compared with control group andquantitated using Matrox Inspector version 2.1 software.

Scavenging of DPPH radicals. The effect of ILL on DPPH radicals was studied by employing the modified method

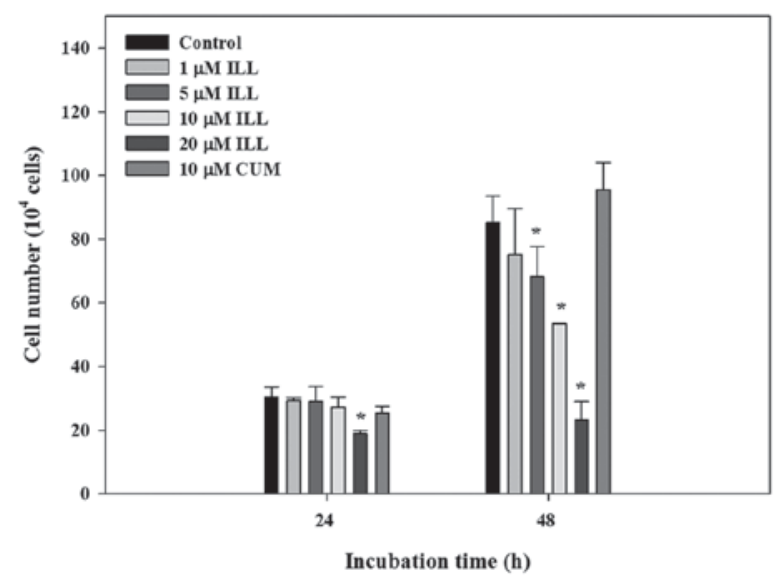

Figure 1. Effects of ILL and CUM on cell growth in human A549 lung cancer cells. Cells were treated with ILL $(1-20 \mu \mathrm{M})$ or CUM $(10 \mu \mathrm{M}$ as the positive control) for 24 and $48 \mathrm{~h}$. Cell numbers were counted using a hemocytometer. Bars represent mean \pm standard deviation $(n=3)$. $P<0.05$ was considered to indicate a statistically significant difference (significance compared with control, $\left.{ }^{*} \mathrm{P}<0.05\right)$. CUM, curcumin; ILL, isolinderalactone.

described by Blois (37) with some modifications as previously described in a study by Lin et al (38). Briefly, $0.1 \mathrm{ml} 1 \mathrm{mM}$ methanol solution of DPPH (cat. no. D9132, Sigma-Aldrich; Merck $\mathrm{KGaA}$ ) was incubated with varying concentrations $(1,5,10$ and $100 \mu \mathrm{M})$ of ILL. After a 30 min incubation period at room temperature, the absorbance of the resulting solution was read at $517 \mathrm{~nm}$ against a blank. The radical scavenging activity was measured as a decrease in the absorbance of DPPH and was calculated using the following equation: Scavenging effect $(\%)=\left[\left(1-\right.\right.$ absorbance $\left._{\text {sample }}\right) /$ absorbance $\left._{\text {control }}\right] \times 100$.

Statistical analysis. Data were expressed as the mean \pm standard deviation and analyzed using one-way analysis of variance followed by Duncan's multiple range test for comparisons of group means. The correlation analysis was conducted using simple linear regression analysis. Statistical analysis was performed using SPSS version 10 (SPSS, Inc. Chicago, IL, USA). $\mathrm{P}<0.05$ was considered to indicate a statistically significant difference.

\section{Results}

Effects of ILL on cell viability. To examine the effect of ILL on cell growth, the numbers of treated A549 cells were counted. As presented in Fig. 1, incubation of A549 cells with 1,5 and $10 \mu \mathrm{M}$ ILL for $24 \mathrm{~h}$ did not decrease cell viability. However, cell viability significantly decreased at $48 \mathrm{~h}$ of incubation with 5, 10 and $20 \mu \mathrm{M}$ ILL. Neither ILL (1-10 $\mu \mathrm{M})$ nor CUM $(10 \mu \mathrm{M})$ inhibited the proliferation of A549 cancer cells at $24 \mathrm{~h}$ of incubation; thus, the following experiments were conducted after a $24 \mathrm{~h}$ incubation.

Effects of ILL on invasion and migration of A549 cancer cells. The anti-invasive and anti-migratory activity of ILL was investigated using transwell inserts, coated with Matrigel in the case of the invasion assay. As presented in Fig. 2, ILL significantly inhibited the invasion of A549 cancer cells in a dose-dependent manner, with a maximum inhibition rate of 


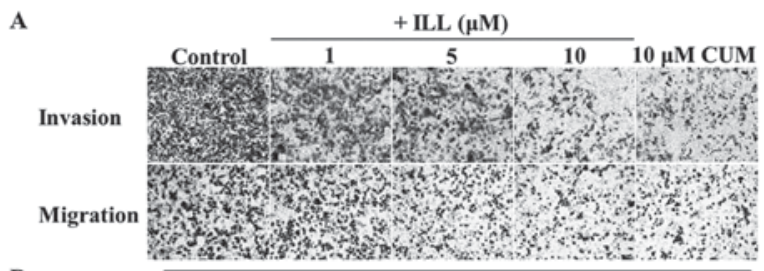

B

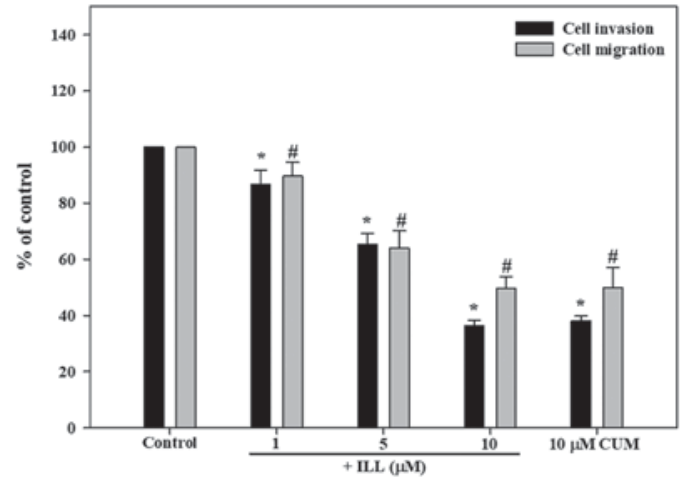

Figure 2. Effect of ILL and CUM on cell invasion and migration of A549 human lung cancer cells. The cells were incubated with ILL $(1,5$ and $10 \mu \mathrm{M})$ and CUM (10 $\mu \mathrm{M}$; as the positive control) for $24 \mathrm{~h}$. (A) Representative phase-contrast photomicrographs (magnification, x100) were captured at $24 \mathrm{~h}$ for the invasion assay and at $12 \mathrm{~h}$ for migration assay. (B) Densitometric analysis of (A). Bars represent mean \pm standard deviation $(n=3) . P<0.05$ was considered to indicate a statistically significant difference (significance compared with control, ${ }^{*} \mathrm{P}<0.05$ or ${ }^{\#} \mathrm{P}<0.05$ ). CUM, curcumin; ILL, isolinderalactone.

$64 \%$ at $10 \mu \mathrm{M}$ of ILL, compared with the control $(\mathrm{P}<0.05)$. As a positive control, the addition of $10 \mu \mathrm{M}$ of CUM significantly inhibited the invasion of A549 cancer cells by $62 \%$ $(\mathrm{P}<0.05)$. Similar to the invasion assay results, ILL inhibited the migration of A549 cells in a dose-dependent manner, with a maximum inhibition of $50 \%$ at $10 \mu \mathrm{M}$ of ILL, compared with the control $(\mathrm{P}<0.05)$.

Effects of ILL on MMP-2 activity and protein expression in A549 cells. The activity of MMP-2 was assayed using gelatin zymography. As presented in Fig. 3, ILL significantly inhibited MMP-2 activity in a dose-dependent manner, with a maximum inhibition of $32 \%$ at $10 \mu \mathrm{M}$ ILL, compared with the control $(\mathrm{P}<0.05)$. The addition of $10 \mu \mathrm{M}$ CUM significantly inhibited MMP-2 activity by $31 \%(\mathrm{P}<0.05)$. As presented in Fig. 3 , the results demonstrated that ILL significantly decreased MMP-2 protein expression levels in a dose-dependent manner $(\mathrm{P}<0.05)$. The addition of ILL at 5 and $10 \mu \mathrm{M}$ significantly inhibited MMP-2 protein expression by 26 and $58 \%$, respectively $(\mathrm{P}<0.05)$. In addition, CUM inhibited MMP-2 protein expression levels by $46 \%$ at $10 \mu \mathrm{M}$. These results were in accordance with those of the MMP-2 activity assay. Collectively, the data of the present study implied that inhibition of MMP-2 protein expression may inhibit the progression of the metastasis of A549 cancer cells.

Effects of ILL on NM23-H1 protein expression in A549 cells. As presented in Fig. 4, ILL significantly up regulated the expression of NM23-H1 protein in a concentration-dependent manner. The addition of ILL at 5 and $10 \mu \mathrm{M}$ significantly increased the protein expression of NM23-H1 by 32 and $61 \%$, respectively $(\mathrm{P}<0.05)$. In addition, CUM increased the expression of NM23-H1 by $35 \%(\mathrm{P}<0.05)$. However, the level

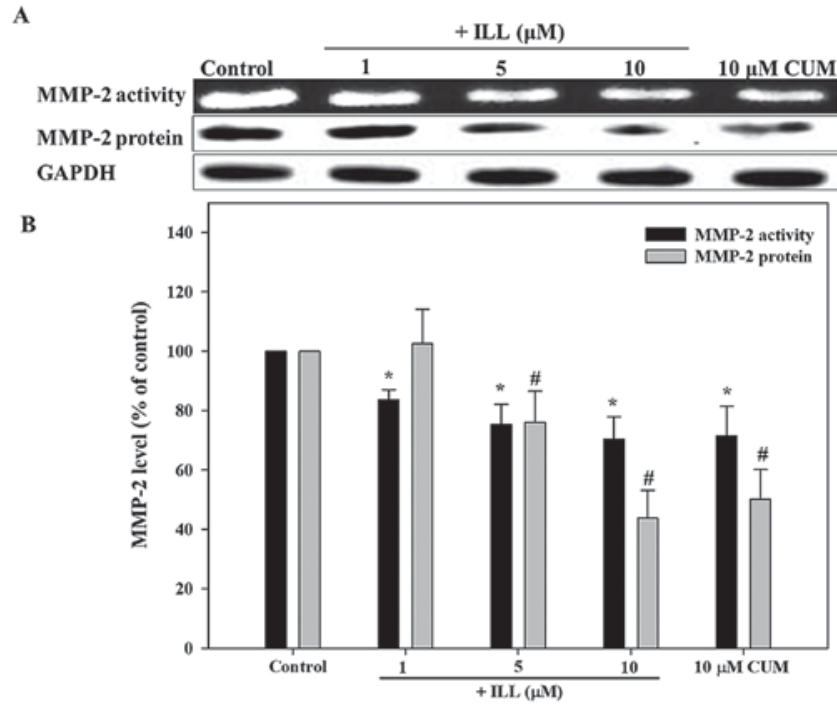

Figure 3. Effect of ILL and CUM on MMP-2 activity and protein expression in A549 human lung cancer cells. The cells were incubated with ILL (1, 5, $10 \mu \mathrm{M})$ and CUM (10 $\mu \mathrm{M}$; as the positive control) for $24 \mathrm{~h}$. (A) Genolytic activity of MMP-2 (as determined by zymographic assay) and western blots of MMP-2 and GAPDH. (B) Relative MMP-2 activity and protein expression (using control as $100 \%$ ). Bars represent mean \pm standard deviation $(n=3) . P<0.05$ was considered to indicate a statistically significant difference (significance compared with control, ${ }^{*} \mathrm{P}<0.05$ or ${ }^{\#} \mathrm{P}<0.05$ ). CUM, curcumin; ILL, isolinderalactone; MMP-2, metalloproteinase-2.

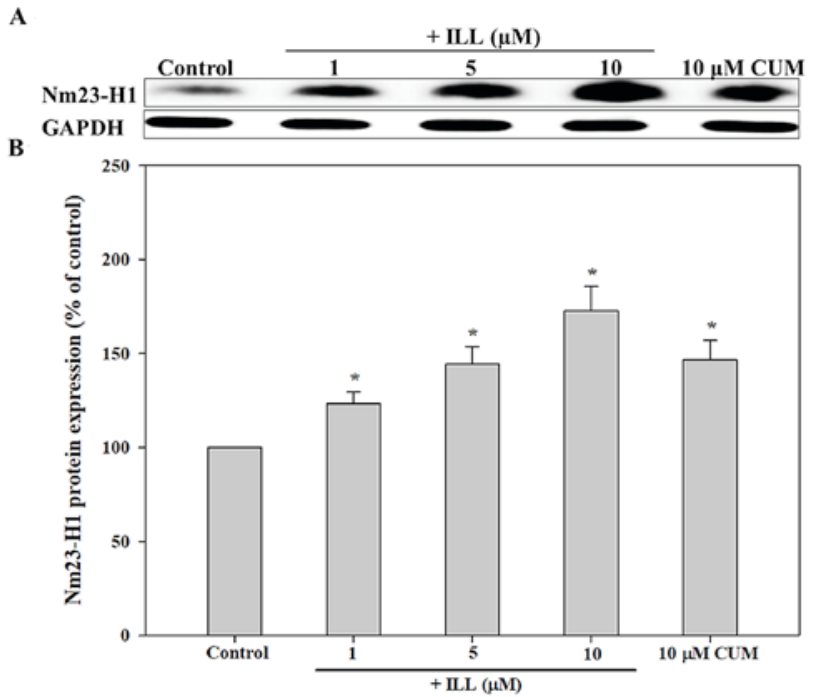

Figure 4. Effect of ILL and CUM on NM23-H1 expression in A549 human lung cancer cells. Cells were incubated with $\operatorname{ILL}(1,5$ and $10 \mu \mathrm{M})$ and CUM (10 $\mu \mathrm{M}$; as the positive control) for $24 \mathrm{~h}$. (A) Western blot analysis of NM23-H1 protein and GAPDH. (B) Densitometric analysis of (A) (using control as $100 \%)$. Bars represent mean \pm standard deviation $(n=3) . P<0.05$ was considered to indicate a statistically significant difference (significance compared with control, $\left.{ }^{*} \mathrm{P}<0.05\right)$. CUM, curcumin; ILL, isolinderalactone; NM23, NME/NM23 nucleoside diphosphate kinase 1.

of TIMP-2 protein in A549 cancer cells was not significantly different among the groups ( $\mathrm{P}>0.05$; data not shown).

Effects of ILL on E-cadherin and $\beta$-catenin protein expression in A549 cells. As presented in Fig. 5, ILL 
A

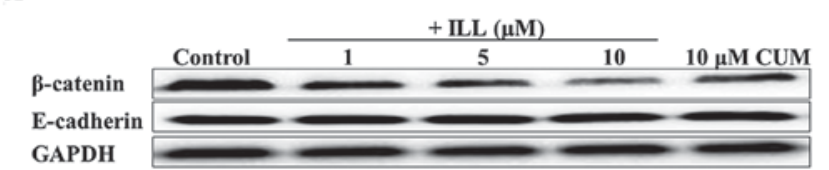

B

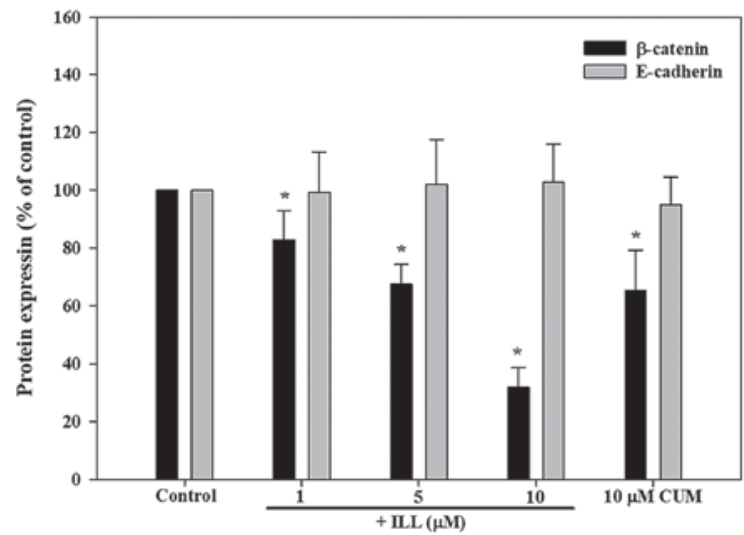

Figure 5. Effect of ILL and CUM on E-cadherin and $\beta$-catenin protein expression in A549 human lung cancer cells. The cells were incubated with ILL $(1,5$ and $10 \mu \mathrm{M})$ and CUM $(10 \mu \mathrm{M}$; as the positive control) for $24 \mathrm{~h}$. (A) Western blots of E-cadherin protein, $\beta$-catenin protein and GAPDH. (B) Densitometric analysis of (A) (using control as 100\%). Bars represent mean \pm standard deviation $(n=3) . P<0.05$ was considered to indicate a statistically significant difference (significance compared with control, ${ }^{*} \mathrm{P}<0.05$ ). CUM, curcumin; ILL, isolinderalactone.

significantly decreased $\beta$-catenin protein expression levels in a dose-dependent manner $(\mathrm{P}<0.05)$. The addition of 5 and $10 \mu \mathrm{M}$ ILL significantly decreased the protein expression levels of $\beta$-catenin by 32.5 and $68.1 \%$, respectively $(\mathrm{P}<0.05)$. In addition, CUM decreased the protein expression of $\beta$-catenin by $34.7 \%(\mathrm{P}<0.05)$. However, the levels of E-cadherin protein in A549 cancer cells were not significantly different between groups.

Antioxidant activity of ILL. DPPH is widely used as a reagent to evaluate free radical scavenging activity of antioxidants (39). The present study indicated that, at a concentration of $1-10 \mu \mathrm{M}$, ILL did not significantly halt the activity of DPPH radicals (data not shown).

Correlation of NM23-H1 protein with MMP-2 activity and MMP-2 protein expression. NM23-H1 protein expression was negatively correlated with MMP- 2 activity $\left(\mathrm{R}^{2}=0.69, \mathrm{P}<0.001\right.$; Fig. 6A) and MMP-2 protein expression $\left(\mathrm{R}^{2}=0.74, \mathrm{P}<0.001\right.$; Fig. 6B) in A549 cancer cells.

\section{Discussion}

Tumor cell metastasis is the leading cause of mortality in patients with lung cancer $(2,4)$. The present study reported that ILL was able to inhibit the invasion and migration of A549 cancer cells, exhibiting a dose-response association. Numerous studies have reported that MMP-2 serves an important role in the invasion and migration of tumor cells and angiogenesis (6-8). Qian et al (12) reported that the expression level of MMP-2 was an independent prognostic factor for patients with non-small cell lung cancer, and was closely associated with
A
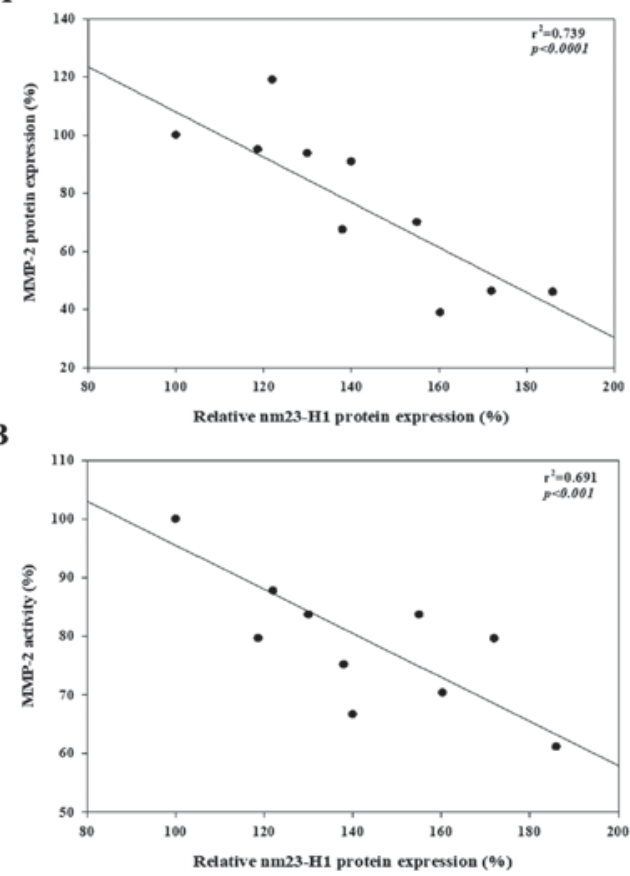

Figure 6. Correlation of NM23-H1 expression (\%) with (A) MMP-2 activity and (B) MMP-2 protein expression (\%). MMP-2, matrix metalloproteinase-2; NM23, NME/NM23 nucleoside diphosphate kinase 1.

pathological grade, clinical stage and lymphatic metastasis. Further analysis of MMP-2 expression and activity revealed that ILL was able to significantly inhibit MMP-2 expression and activity, again exhibiting a dose-response association. The inhibition trend of MMP-2 was similar to that of its invasion and migration-associated properties. The results of the present study indicated that the ability of ILL to inhibit the invasion and migration of A549 cells might be associated with reduced protein expression and secretion of MMP-2 in lung cancer cells. TIMP-2 is the endogenous inhibitor of MMP-2, and can combine extra cellularly with MMP-2 to inhibit MMP-2 activity $(40,41)$. However, the present study did not observe any significant increase in TIMP-2 protein expression brought about by ILL (data not shown). It is thus speculated that the inhibition of MMP-2 by ILL was not associated with any mechanisms involving TIMP-2 expression.

The gene encoding NM23-H1 is a suppressor of tumor metastasis; research has revealed that it may reduce MMP-2 and -9 expression in various types of cancer cells $(18-21,35,42,43)$. Boissan et al (19) previously reported that NM23-H1 silencing promotesthe extracellular matrix invasion of $\mathrm{HepG} 2$ cells by up regulating numerous MMPs, including MMP-2. The results of the present study demonstrated that ILL was able to significantly increase NM23-H1 expression in a dose-dependent manner. Additionally, NM23-H1 expression does not affect the status of MMP-2 and -9 for certain tumor cells: Examples include oral cancer cell lines (44), cervical cancer (45) and gastric cancer (46). It is speculated that this may be associated with tumor cell type and the extent of oncogenesis. Thus, the ILL treatment group exhibited a negative correlation with respect to NM23-H1 protein expression $\left(\mathrm{R}^{2}=0.74, \mathrm{P}<0.001\right)$ and MMP-2 protein expression $\left(\mathrm{R}^{2}=0.69, \mathrm{P}<0.001\right)$ and 
activity; however, it remains unclear whether the alterations in MMP-2 were correlated with the alterations in NM23-H1.

Numerous studies have reported that NM23-H1 is critical for control of cell-cell adhesion and cell migration during the early stages of the invasive program in tumor cells $(19,43,47)$. Che et al (43) transfected NM23-H1 cDNA into the human non-small cell lung cancer L9981 cell line, which is negative NM23 expression, and reported that, via increasing $\beta$-catenin and E-cadherin protein expression, NM23-H1 may simultaneously inhibit MMP-2 and vascular endothelial growth factor protein expression, inhibiting cell mobility and metastasis. In another previous study, it was reported that NM23-H1 silencing may disrupt the cell-cell adhesion mediated by E-cadherin, resulting in $\beta$-catenin nuclear translocation in HepG2 cells (19). $\beta$-catenin is an important component of cell-cell adhesion $(19,43,48)$. However, the loss of cell-cell adhesion due to the activation of $\beta$-catenin can increase the migratory potential of tumor cells (48). In the present study, ILL treatment significantly decreased $\beta$-catenin protein expression in a dose-dependent manner. We therefore hypothesize that the mechanisms of action of ILL, with respect to the reduction of A549 cancer cell migration, may be associated with the inhibition of $\beta$-catenin by up regulating the expression of NM23-H1 genes.

Recent evidence has also indicated that the transcriptional factor forkhead box O3 (FOXO3) in A549 cancer cells will reduce the expression of NM23-H1 (49). Additionally, Gong et al (50) also reported that STAT3 activation was inhibited by NM23-H1. STAT3 may bind directly to the STAT3 binding site on the NM23-H1 promoter and activate NM23-H1 expression, whereas its own expression may be inhibited, thereby reducing the metastasis of A549 cancer cells. Yen et al (27) also demonstrated that ILL is able to reduce microRNA hsa-miR-30c expression, increase SOCS3 activation and inhibit STAT3 phosphorylation. In this manner, cell apoptosis was induced in human breast cancer cells. In light of these findings, further research is required to determine whether the inhibition of A549 cancer cell metastasis by ILL is associated with the regulation of STAT3 or FOXO3 activity by NM23-H1.

The production of reactive oxygen species (ROS) in tumor cells may promote the invasion and migration of tumor cells (51). Therefore, the inhibition of cancer cell metastasis could be partially linked to the inhibition of ROS production. 2,2-Diphenyl-1-picrylhydrazyl (DPPH) analysis is widely used to assess the effects of various antioxidants on the efficiency of free radical scavenging (52). In this study, 1-10 $\mu \mathrm{M}$ of ILL did not significantly reduce the activity of DDPH free radicals (data not shown), and it is thus speculated that the inhibition of A549 lung cancer cell metastasis may be not be associated with the clearance of ROS.

On the basis of the aforementioned results and to the best of our knowledge, the present study is the first to confirm that ILL can significantly inhibit the invasion and migration of A549 lung cancer cells; the possible molecular mechanisms may constitute increases in NM23-H1 expression, and the inhibition of MMP-2 activity and protein expression, as well as the inhibition of $\beta$-catenin protein expression. However, further investigation into the relevant mechanisms of metastasis is required.

\section{Acknowledgements}

The present study was supported by the Ministry of Science and Technology, Republic of China (Taiwan) (grant nos. MOST 103-2221-E-025-013 and 104-2221-E-025-014). The authors thank Mr. Jia-Yi Ting (Department of Nutrition, Hungkuang University, Taichung, Taiwan, R.O.C), Ms Wei-Zhu Wang (Department of Beauty Science, National Taichung University of Science and Technology, Taichung, Taiwan, R.O.C), Ms Yi-Yun Lin (Department of Nutrition, Hungkuang University) and Ms Tsen-Lin Shih (Department of Nutrition, Hungkuang University) for their technical support.

\section{References}

1. Torre LA, Bray F, Siegel RL, Ferlay J, Lortet-Tieulent J and Jemal A: Global cancer statistics, 2012. CA Cancer J Clin 65: 87-108, 2015.

2. Mehlen P and Puisieux A: Metastasis: a question of life or death. Nat Rev Cancer 6: 449-458, 2006.

3. Ihde DC: Chemotherapy of lung cancer. N Engl J Med 327: 1434-1441, 1992

4. Stewart DJ: Tumor and host factors that may limit efficacy of chemotherapy in non-small cell and small cell lung cancer. Crit Rev Oncol Hematol 75: 173-234, 2010.

5. Reka AK, Goswami MT, Krishnapuram R, Standiford TJ and Keshamouni VG: Molecular cross-regulation between PPAR- $\gamma$ and other signaling pathways: Implications for lung cancer therapy. Lung Cancer 72: 154-159, 2011.

6. Fidler IJ and Kripke ML: Metastasis results from preexisting variant cells within a malignant tumor. Science 197: 893-895, 1977.

7. Halbersztadt A, Halon A, Pajak J, Rabczynski J and St Gabrys M: The role of matrix metalloproteinases in tumor invasion and metastasis. Ginekol Pol 77: 63-71, 2006.

8. Chuang, CH, Liu CH, Lu TJ and Hu ML: Suppression of alpha-tocopherol ether-linked acetic acid in VEGF-induced angiogenesis and the possible mechanisms in human umbilical vein endothelial cells. Toxicol Appl Pharmacol 281: 310-316, 2014.

9. Birkedal-Hansen H: Proteolytic remodeling of extracellular matrix. Curr Opin Cell Biol 7: 728-735, 1995.

10. Liotta LA, Tryggvason K, Garbisa S, Hart I, Foltz CM and Shafie S: Metastatic potential correlates with enzymatic degradation of basement membrane collagen. Nature 284: 67-68, 1980.

11. Liabakk NB, Talbot I, Smith RA, Wilkinson K and Balkwill F: Matrix metalloprotease 2 (MMP-2) and matrix metalloprotease 9 (MMP-9) type IV collagenases in colorectal cancer. Cancer Res 56: 190-196, 1996.

12. Qian Q, Wang Q, Zhan P, Peng L, Wei SZ, Shi Y and Song Y: The role of matrix metalloproteinase 2 on the survival of patients with non-small cell lung cancer: A systematic review with meta-analysis. Cancer Invest 28: 661-669, 2010.

13. Steeg PS, Bevilacqua G, Kopper L, Thorgeirsson UP, Talmadge JE, Liotta LA and Sobel ME: Evidence for a novel gene associated with low tumor metastatic potential. J Nati Cancer Inst 80: 200-204, 1988.

14. Leone A, Flatow U, King CR, Sandeen MA, Margulies IM, Liotta LA and Steeg PS: Reduced tumor incidence, metastatic potential, and cytokine responsiveness of NM23-transfected melanoma cells. Cell 65: 25-35, 1991.

15. Liu F, Zhang Y, Zhang XY and Chen HL: Transfection of the $\mathrm{nm} 23-\mathrm{H} 1$ gene into human hepatocarcinoma cell line inhibits the expression of sialyl Lewis X, alpha 1,3 fucosyltransferase VII, and metastatic potential. J Cancer Cancer Res Clin Oncol 128: 189-196, 2002.

16. Khan MH, Yasuda M, Higashino F, Haque S, Kohgo T, Nakamura M and Shindoh M: Nm23-H1 suppresses invasion of oral sqamous cell carcinoma-derived cell lines without modifying matrix metalloproteinase-2 and matrix metalloproteinase- 9 expression. Am J Pathol 158: 1785-1791, 2001.

17. Yokdang N, Nordmeier S, Speirs K, Burkin HR and Buxton IL: Blockade of extracellular NM23 or its endothelial target slows breast cancer growth and metastasis. Integr Cancer Sci Ther 2: 192-200, 2015. 
18. Boissan M and Lacombe ML: Nm23, an example of a metastasis suppressor gene. Bull Cancer 99: 431-440, 2012.

19. Boissan M, De Wever O, Lizarraga F, Wendum D, Poincloux R, Chignard N, Desbois-Mouthon C, Dufour S, Nawrocki-Raby B and Birembaut P: Implication of metastasis suppressor NM23-H1in maintaining adherens junctions and limiting the invasive potential of human cancer cells. Cancer Res 70:7710-7722, 2010.

20. You J, Chang R, Liu B, Zu L and Zhou Q: Nm23-H1 was involved in regulation of KAI1 expression in high-metastatic lung cancer cells L9981. J Thorac Dis 8: 1217-1226, 2016.

21. Liu YB, Gao SL, Chen XP, Peng SY, Fang HQ, Wu YL, Peng CH Tang Z, Xu B, Wang JW, et al: Expression and significance of heparanase and NM23-H1 in hepatocellular carcinoma. World J Gastroenterol 11: 1378-1381, 2005

22. Luo Y, Liu M, Yao X, Xia Y, Dai Y, Chou G and Wang Z: Total alkaloids from Radix Linderae prevent the production of inflammatory mediators in lipopolysaccharide-stimulated RAW 264.7 cells by suppressing NF-kappaB and MAPKs activation. Cytokine 46: 104-110, 2009.

23. Li YM, Ohno Y, Minatoguchi S, Fukuda K, Ikoma T; Ohno T, Akao S, Takemura G, Gotou K and Fujiwara H: Extracts from the roots of Lindera strychifolia induces apoptosis in lung cancer cells and prolongs survival of tumor-bearing mice. Am J Chin Med 31: 857-869, 2003

24. Gan LS, Zheng YL, Mo JX, Liu X, Li XH and Zhou CX Sesquiterpene lactones from the root tubers of Lindera aggregata. J Nat Prod 72: 1497-1501, 2009.

25. Lin CT, Chu FH, Chang ST, Chueh PJ, Su YC, Wu KT and Wang SY: Secoaggregatalactone-A from Lindera aggregate induces apoptosis in Human Hepatoma Hep G2 Cells. Planta Med 73: 1548-1553, 2007

26. Ohno T, Nagatsu A, Nakagawa M, Inoue M,Li YM, Minatoguchi S, Mizukami $\mathrm{H}$ and Fujiwara $\mathrm{H}$ : New sesquiterpene lactones from water extract of the root of Lindera strychnifolia with cytotoxicity against the human small cell lung cancer cell, SBC-3. Tetrahedron Lett 46: 8657-8660, 2005.

27. Yen MC, Shih YC, Hsu YL, Lin ES, Lin YS, Tsai EM, Ho YW, Hou MF and Kuo PL: Isolinderalactone enhances the inhibition of SOCS3 on STAT3 activity by decreasing miR-30c in breast cancer. Oncol Rep 35: 1356-1364, 2016.

28. Chang WA, Lin ES, Tsai MJ, Huang MS and Kuo PL: Isolinderalactone inhibits proliferation of A549 human non-small cell lung cancer cells by arresting the cell cycle at the G0/G1 phase and inducing a Fas receptor and soluble Fas ligand-mediated apoptotic pathway. Mol Med Rep 9: 1653-1659, 2014.

29. Ahmad A, Sayed A, Ginnebaugh KR, Sharma V, Suri A, Saraph A, Padhye S and Sarkar FH: Molecular docking and inhibition of matrix metalloproteinase-2 by novel difluorinatedbenzylidene curcumin analog. Am J Transl Res 7: 298-308, 2015

30. Kumar D, Kumar M, Saravanan C and Singh SK: Curcumin A potential candidate for matrix metalloproteinase inhibitors Expert Opin Ther Targets 6: 959-972, 2012

31. Yeh SL, Yeh CL, Chan ST and Chuang CH: Plasma rich in quercetin metabolites induces $\mathrm{G}_{2} / \mathrm{M}$ arrest by upregulating PPAR- $\gamma$ expression in human A549 lung cancer cells. Planta Medica 77: 992-998, 2011

32. Pettit GR, Hoard MS, Doubek DL, Schmidt JM, Pettit RK, Tackett LP and Chapuis JC: Antineoplastic agents 338. The cancer cell growth inhibitory. Constituents of Terminnalia arjuna (Combretaceae). J Ethnopharmacol 53: 57-63, 1996.

33. Tholudur A, Giron L, Alam K, Thomas T, Garr E, Weatherly G, Kulowiec K, Quick M and Shepard S: Comparing automated and manual cell counts for cell culture applications. Bio Process Int 28-34, 2006

34. Repesh LA: A new in vitro assay for quantitating tumor cell invasion. Invasion Metastasis 9: 192-208, 1989.
35. Chuang CH, Yeh CL, Yeh SL, Lin ES, Wang LY and Wang YH Quercetin metabolites inhibit MMP-2 expression in A549 lung cancer cells by PPAR- $\gamma$ associated mechanisms. J Nutr Biochem 33: 45-53, 2016.

36. Hwang HJ, Park HJ, Chung HJ, Min HY, Park EJ, Hong JY and Lee SK: Inhibitory effects of caffeic acid phenethyl ester on cancer cell metastasis mediated by the down- regulation of matrix metalloproteinase expression in human HT1080 fibrosarcoma cells. J Nutr Biochem 17: 356-362, 2006.

37. Blois MS: Antioxidant determinations by the use of a stable freeradical. Nature 26: 1199-1200, 1958.

38. Lin ES, Yang CT, Chou HJ and Chang TT: Screening of antioxidant activities by the edible Basidiomycete Antrodia cinnamomea strains in submerged culture. J Food Biochem 34: 1141-1156, 2010.

39. Ak T and Gülçin I: Antioxidant and radical scavenging properties of curcumin. Chem Biol Interact 174: 27-37, 2008.

40. Marino N, Nakayama J, Collins JW and Steeg PS: Insights into the biology and prevention of tumor metastasis provided by the Nm23 metastasis suppressor gene. Cancer Metastasis Rev 31: 593-603, 2012.

41. Crocker SJ, Pagenstecher A and Campbell IL: The TIMPs tango with MMPs and more in the central nervous system. J Neurosci Res 75: 1-11, 2004.

42. Ohba K, Miyata Y, Koga S, Kand S and Kanetake H: Expression of nm23-H1 gene product in sarcomatous cancer cells of renal cell carcinoma: Correlation with tumor stage and expression of matrix metalloproteinase-2, matrix metalloproteinase- 9 , sialyl Lewis X, and c-erbB-2. Urology 65: 1029-1034, 2005.

43. Che G, Chen J, Liu L, Wang Y, Li L, Qin Y and Zhou Q: Transfection of NM23-H1 increased expression of $\beta$-Catenin, E-Cadherin and TIMP-1 and decreased the expression of MMP-2, CD44v6 and VEGF and inhibited the metastatic potential of human non-small cell lung cancer cell line L9981. Neoplasma 53: 530-537, 2006.

44. Khan MH, Yasuda M, Higashino F, Haque S, Kohgo T, Nakamura M and Shindoh M: Nm23-H1 suppresses invasion of oral sqamous cell carcinoma-derived cell line without modifying matrix metalloproteinase-2 and matrix metalloproteinase-9 expression. Am J Pathol 158: 1785-1791, 2001.

45. Wang PH, Yang SF, Chen GD, Han CP, Chen SC, Lin LY and Ko JL: Human nonmetastatic clone 23 type 1 gene suppresses migration of cervical cancer cells and enhances the migration inhibition of fungal immunomodulatory protein from Ganoderma tsugae. Reprod Sci 14: 475-485, 2007.

46. Wang LB, Jiang ZN, Fan MY, Xu CY, Chen WJ and Shen JG: Changes of histology and expression of MMP-2 and nm23-H1 in primary and metastatic gastric cancer. World J Gastroenterol 14: $1612-1616,2008$

47. Zhao R, Gong L, Li L, Guo L, Zhu D, Wu Z and Zhou Q: NM23-H1is a negative regulator of TGF- $\beta 1$-dependent induction of epithelial-mesenchymal transition. Exp Cell Res 319: 740-749, 2013.

48. Vaid M, Prasad R, Sun Q and Katiyar SK: Silymarin targets $\beta$-catenin signaling in blocking migration/invasion of human melanoma cells. PLoS One 6: e23000, 2011.

49. Zhang L, Li L, Wei H, Guo L, Ai C, Xu H, Wu Z and Zhou Q; Transcriptional factor $\mathrm{FOXO} 3$ negatively regulates the expression of NM23-H1 in non-small cell lung cancer. Thorac Cancer 7: 9-16, 2016.

50. Gong L, Wu Z, Guo L, Li L, Zhao R, Zhu D and Zhou Q: Metastasis suppressor Nm23-H1 inhibits STAT3 signaling via a negative feedback mechanism. Biochem Biophys Res Commun 434: 541-546, 2013

51. Szatrowski TP and Nathan CF: Production of large amounts of hydrogen peroxide by human tumor cells. Cancer Res 51 794-798, 1991.

52. Ak T and Gülçin I: Antioxidant and radical scavenging properties of curcumin. Chem Biol Interact 174: 27-37, 2008. 